\title{
Woman's AIDS death in Japan produces shock waves
}

\section{Tokyo}

THE first Japanese woman to be officially recognized as a victim of AIDS (acquired immune defiency syndrome), died last week, awakening Japan to the fact that the disease is not confined to homosexuals and haemophiliacs.

According to the Health and Welfare Ministry, the number of AIDS cases in Japan totals $26 ; 18$ patients have already died. There may be more unreported cases.

More than 50 per cent of Japanese AIDS cases are haemophiliacs; nearly all the others are homosexuals. The large percentage of haemophiliacs has arisen because of a prime infection route via imported blood products, mainly from the United States (see Nature 315, 8; 1986).

Blood tests since 1984 establish that about 30 per cent of Japan's 4,000-5,000 haemophiliacs have been exposed to AIDS. Japan's first AIDS victim was a haemophiliac who developed the disease in 1981, and antibodies to the AIDS virus have been detected in sera of haemophiliac patients dating back to 1980 . It has been suspected since 1985 that thousands of homosexuals carry the virus, and the first homosexual victim developed AIDS in 1982 . Yet only 14 haemophiliacs and 10 homosexuals have been officially recognized to have AIDS, fewer than 1 per cent of the inferred number of carriers.

There have been problems recognizing the disease. The latest victim, a Kobe prostitute, first approached a hospital in July last year complaining of fatigue and severe diarrhoea. In October she was diagnosed as having pneumonia and was transferred to a second hospital. Unresponsive to treatment, she was moved to a third hospital in December. Only then were blood samples taken to check for AIDS. She was officially recognized as an AIDS sufferer by the Health and Welfare Ministry on 17 January, three days before she died.

Doctors may be reluctant to report patients to the ministry. Those treating haemophiliacs are particularly concerned that their patients should not be ostracized by society or barred from schools. There is no legal requirement to report cases, only "administrative guidance"; patients with AIDS-related complex are not reported and nor are infection routes.

The ministry is considering the introduction of a new law to make AIDS a notifiable disease. But some members of the ministry's "AIDS Countermeasures Experts Conference", would like to ensure anonymity for haemophiliacs.

A third brake on the reporting of AIDS may be the ministry itself. Japan's first
AIDS victim died in July 1983. But the first report of AIDS was not released until March 1985, after one of the ministry's advisers had published the results of blood tests in a medical journal (see Nature 315, $8 ; 1985)$.

A chief concern is to avoid "panic and confusion" by setting up advisory services before making public announcements. In step with this, since November last year, the Japanese Red Cross has been screening all blood donors for AIDS and ATL (adult T-cell leukaemia) (See Nature 323, $384 ; 1986)$. But the ministry decided that although AIDS carriers would be told that they were infected, ATL carriers would not.

The reason is one of numbers and facilities. Only ten AIDS carriers have so far been found among two million blood donors, but more than 1 per cent of Japan's nearly 9 million donors are believed to carry ATL. Although only about one in 2,000 ATL carriers develop the disease, usually in their forties or fifties, ATL is fatal. As evidence mounts that the virus is transmitted from mother to child through mother's milk simple advice not to breast-feed could save lives. But the

ministry is not notifying ATL carriers because of a "lack of appropriate administrative provisions".

Following the announcement of Japan's first female AIDS victim, there was a flood of calls in the Kobe area seeking advice and blood tests, mainly from men who had visited 'soapland' (massage parlours) and other prostitutes. The public is now aware that Japanese women can catch AIDS, but ignorance about the disease is still rife. At a public hearing on AIDS in Yokosuka last week, audience attention focused on such questions as whether AIDS can be caught from train straps.

The government has boosted funding for AIDS research in fiscal year 1987 to Y155 million (about US \$1 million), Y112 million up on last year. Part of the funds will be used to develop drugs to combat the disease, including a Chinese herbal medicine derived from liquorice. But the funds allotted to AIDS research and prevention in Japan pale into insignificance when compared with the over $\$ 500$ million requested for the 1988 US budget, and only Y7 million has been put aside for administration costs and public information. Leaflets on AIDS are available on request at local ward offices and health centres, but there have been no major publicity campaigns as seen in the West.

David Swinbanks

\section{World human-powered flight record}

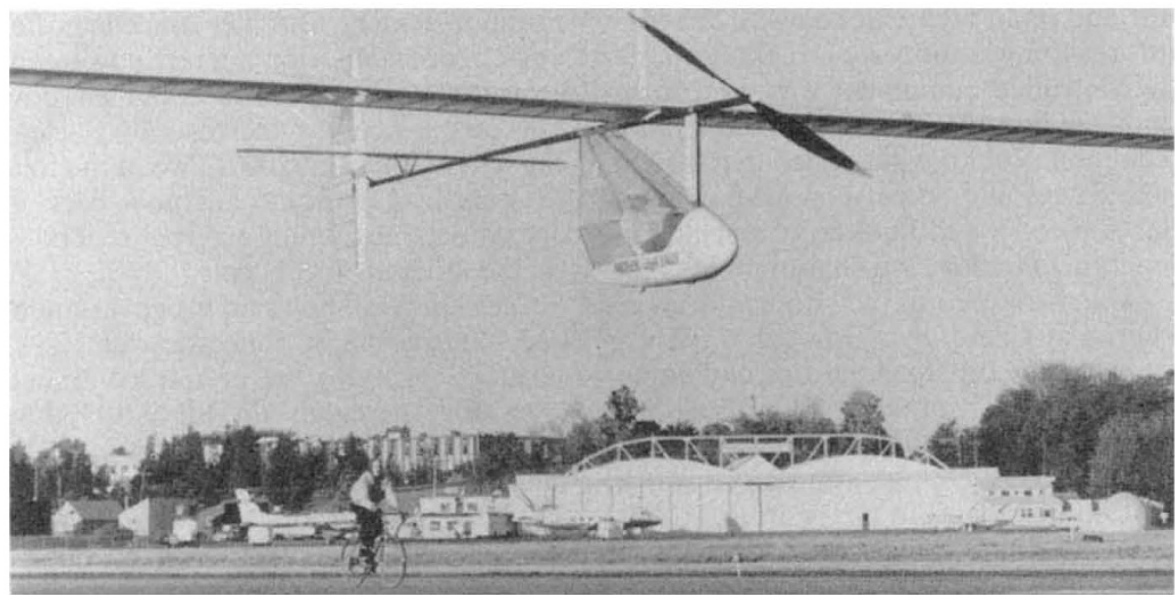

\section{Washington}

A WORLD distance record for humanpowered flight was set last week by Glenn Tremml, piloting a craft designed by Massachusetts Institute of Technology engineers. Tremml stayed aloft 2 hours, 13 minutes and 14 seconds, travelling $59.9 \mathrm{~km}$ (37.2 miles) over the Mojave desert at Edwards Air Force Base in California. Earlier last week, pilot Lois McCallin set a woman's distance record with a ten-mile flight. The craft, the Michelob Light Eagle, is a prototype for a second plane that will attempt to fly $111 \mathrm{~km}(69$ miles) from Crete to the Greek mainland later this year, recreating the feat of the mythical Greek character Daedalus. The plane flies between 1.5 and 3 metres (5-10 feet) off the ground and averages about $25 \mathbf{~ k m}$ (16 miles) per hour. It weighs $40 \mathrm{~kg}(88 \mathrm{lb})$, is 9 metres ( 29.6 feet) long, and has a wingspan of 31.1 metres (102 feet). The aircraft frame is constructed of a carbon-fibre material called Thornel bonded by epoxy into a strong, lightweight design. One hundred and twenty ribs of foam and aircraft plywood give the plane aerodynamic shape. The wings are covered with plastic, and the body of the plane with a synthetic cloth.
Joseph Palca 